Project Organising as a Problem in Information

Graham M Winch

Manchester Business School

graham.winch@mbs.ac.uk

\begin{abstract}
One of the most influential perspectives in business and management has been the Carnegie School, represented by such luminaries as James March, Hebert Simon, Oliver Williamson and Zur Shapira. The perspective underpins much of contemporary organisation theory and organisational economics. Yet there have only been limited attempts to apply it to the domain of construction economics and management. An important exception to this statement is the application of Willamson's transaction cost economics to the governance of inter-firm relations in construction, but, the paper will argue, the opportunity is presently being missed for a more thorough-going application. The aim of this paper, therefore, is to suggest what such an application might look like and why it might be useful in simulating new lines of research enquiry. The paper will articulate the principal tenets of the Carnegie School and the central role of uncertainty and bounded rationality in those tenets. It will then draw on the contributions to organisation theory of the Carnegie School to conceptualise project organising as a problem in information, and suggest a new perspective on the microfoundations for that theory.
\end{abstract}

Keywords

Project organisation; Carnegie School; organisation theory; microfoundations, organisational economics. 
Project Organising as a Problem in Information

Introduction

One of the great strengths of domain-focused research programmes rather than disciplinefocused research programmes is that they can become the fount of multi-disciplinary research. This is well demonstrated by the research programme in construction economics and management that evolved from the 1980s at the Bartlett School, University College London. Graham Ive has played an outstanding role in developing the economics of construction through teaching on the MSc Construction Economics and Management and in his micro- and macro-economic texts (Gruneberg and Ive 2000; Ive and Gruneberg 2000). Rooted in this context, this paper attempts to do two things. First, it articulates a theoretical exposition of the teaching on construction project management that complemented the teaching on construction economics during the 1990s which conceptualised - to paraphrase Graham Ive's words - project management as a problem in information. On this basis a perspective on project organisation as an information processing system was developed (Winch 2002; 2010). Second, it attempts to move that perspective forwards by examining the microfoundations (Van de Ven and Lifschitz 2013) of that theoretical exposition to yield new insights for research into project organisations and their management.

Core teaching in construction management on the MSc during the 1990s emphasised equally the management of the construction firm and the construction project (Winch 1989). For the management of the construction firm, teaching drew mainly on the positioning school (e.g. Porter 1980) for the strategy element and, at least initially, Katz and Kahn (1978) for the organisational element in a conscious rejection of the systems approach (Kast and Rosenzweig 1974) which had dominated teaching on the MSc during 
the 1980s. The challenges of adapting these literatures to the distinctive features of firms in the construction sector stimulated an important theme for research which initially produced Winch and Schneider (1993) on the strategic management of architectural practice. More recent empirical work within this theme has focused on the internationalisation and yielded most recently Winch (in press) on the relationship between home market positioning and internationalisation strategies for architectural practice.

Teaching on the management of the construction project also rejected the systems approach as epitomised by Cleland and King (1983) and turned instead to the work of the Carnegie School (Cyert and March 1992; March and Simon 1993; Simon 1976) for inspiration. Two members of the second generation of Carnegie scholars were particularly influential. Galbraith (1977) had developed his research (1970) on the organisation of aircraft development projects into a more general theory of organisations as information processing systems in which contingency was operationalised in terms of the different information processing requirements of the organisation or sub-organisational unit. Galbraith's work focused on internal organisation, but construction project coalitions consist of multiple organisations. Williamson (1975; 1985), in his transaction cost economics, developed a theory of the relationships between firms (and indeed within firms) which was theoretically compatible with Galbraith's information processing approach.

The paper first articulates the Carnegie contribution to organisation theory since over the last 60 years, and also shows its contemporary relevance dubbed by some as "neoCarnegie" (Gavetti et al 2012). On this sound theoretical basis, the perspective on project organising of projects as information processing systems is presented, and the importance of the cognitive condition of uncertainty in that perspective. Next, two areas of 
construction project management research where the potential for the information processing perspective to generate new and interesting lines of enquiry are explored. However, many are put off by the microfoundations of the Carnegie approach, particularly in its transaction cost economics incarnation, and so a new "model of man" as the decisionmaker as a prudentially reasonable sensemaker is developed. Conclusions follow.

The Carnegie Perspective on Organisations and Their Management

The Carnegie School set out to challenge the accepted wisdom of the day. Simon's initial aim (1976; first published 1947) was to put the "science" of public administration on a more sound footing than the Progressive-era nostrums he inherited by focusing on decision-making (Cohen 2007). However, the main focus of the research programme became the critique of the neo-classical economics and decision sciences which then dominated the theory of the firm. Friedman (1953) argued in an influential argument on methodology that the behavioural plausibility of the (to use a contemporary formulation) microfoundations of economics were of no concern if the theory successfully predicted empirical outcomes at the level of analysis under investigation. The Carnegie school argued for behavioural plausibility and, in particular, Simon (1955) developed the argument that decision-makers were boundedly rational. That is, they tried to be as rational as they could, but were constrained by both lack of information about the true state of affairs and constrained by information processing capacity from acting in a fully rational way with complete information as presumed by the dominant theory of the firm. This led to a set of "frontal assaults" (Cyert and March 1993: 8) on the standard theory of the firm.

This concern for behavioural plausibility meant that research had to open up the "black box" of the firm "to supplement the study of market factors with an examination of the internal operation of the firm - to study the effects of organizational structure and 
conventional practice on the development of goals, the formation of expectations and the execution of choices" (Cyert and March 1993: 1). This in a context where organisations are understood sui generis as "systems of coordinated action among individuals and groups whose preferences, information, interests or knowledge differ" (March and Simon 1993: 2). These concerns laid the foundations for a "behaviorally plausible, decision-centred perspective on organizations" (Gavetti et al 2007: 525) which has been enormously influential. Amongst others, it laid the foundations for programmes of research that led to two Nobel Prizes for economics (Simon and Williamson).

Further generations of scholars carried this work forward; we will review here those with most relevance for projects and their management - Gavetti et al (2012) provide a broader perspective. Williamson $(1975 ; 1985)$ focused on one particular managerial decision - the make or buy decision - which has enormous implications for the boundary, and hence theory, of the firm. His transaction cost economics does not directly challenge the neoclassical economics of production costs but argues that transaction costs are also significant in economic decision-making. To the behaviour of bounded rationality as a result of uncertainty, Williamson added the behaviour of opportunism as a result of asset specificity, in which holders of scarce and valued assets opportunistically exploit their position usually by charging higher prices. The two in combination render the neo-classical theory of contract where prices are freely bargained under full information nugatory and, drawing on Macneill (2001), Williamson $(1975 ; 1985)$ explored the world of relational contracts. On projects, Stinchcombe (1990) extends this line of enquiry to the relational properties of standard forms of contract, while Masten et al (1991) identify the "hold-up problem" where holders of asset specificities are on the project's critical path. 
Galbraith (1977) focuses more on internal organisation. His principal concern was the problem of co-ordination within the organisation. The efficiency properties of the division of labour argue for breaking production down into its constituent activities, while contingency theory (Perrow 1967) argues that these constituent activities will be most efficiently organised differently. This beneficial differentiation then poses the problem of co-ordination, or integration, of these diverse activities. Drawing on his work on project coordination in Boeing, Galbraith develops a framework for understanding coordination processes in organisations varying from liaison roles, through project management, to information systems. He places flows of information at the core of his organisation theory. These information flows may initiate and control flows of materials (Winch 1994), but, for Galbraith, managerial and organisational processes are essentially about information flows.

Within the third Carnegie generation, Shapira (1997) and Shapira and Berndt (1997) focused more directly on decision-making. In their empirical work on risk-taking, the importance of perceptions of managerial control in the risk propensity of managers is emphasised. Focusing more specifically on major construction projects, Shapira and Berndt (1997) developed a model of investment appraisal decision-making on projects which draws heavily on the core ideas of the Carnegie School.

Projects as a Problem in Information

Projects are inherently uncertain endeavours deploying substantial resources in the aspiration of achieving desired future states (Winch 2010) - in construction this desired future state is embodied in some kind of built facility. Although the uniqueness of individual projects can be overstated, there are always some aspects of the project which are unique. Even for modern methods of construction, the specification of foundations and service connections is site specific and the demand conditions for the use of those buildings 
inevitably lie in the future. The past is only a partial guide to the future on projects, and, more frustratingly, we cannot be sure how partial that guide is at the inception of any particular project. The strength of the Carnegie School perspective for development of theory in construction management - and, I would submit, in construction economics - is that it provides a theoretical framework for working through the implications of projects as a problem in information. During the early 1990s discussions around the development of management teaching on the MSc programme inspired Graham Ive to formulate the nub of the issues as projects as a problem in (the lack of) information, and thereby inspired the perspective on project organizations as information processing systems (Winch 2004) which evolved as teaching developed during the 1990s and reached its fullest expression to date in Winch $(2002 ; 2010)$.

The central assertion of this perspective is that projects - or more strictly, decision-makers on projects - face irreducible uncertainty when making the decisions required to advance the project through its life-cycle. "Uncertainty" is here defined as the lack of information required to make a decision which is given by the amount of information required for a decision less the amount available (Galbraith 1977); the catch being that there is no certainty as to the total amount of information required! This definition is clearly aligned with that provided earlier by Knight (2002; first published 1921) who distinguished between "uncertainty" and "risk" where there is enough prior information to develop a probability distribution of an event occurring. It also aligns with Keynes' assertion that uncertainty is the condition where "there is no scientific basis on which to form any calculable probability whatsoever" (1937: 214). This definition is clearly distinguished from that pervading in the decision sciences and hence the project risk management literature to the effect that a "risk" is a possible future event while "uncertainty" is the probability of that event occurring. This perspective is directly derived from neo-classical economics (Winch and 
Maytorena 2011) and hence at odds with Simon's critique of that paradigm's assumptions of full rationality.

Projects do not consist of a decision at a single point in time; rather they are, in many ways, an ever deepening and broadening sequence of decisions through time (Winch 2010). We need, therefore, to distinguish between the initial state of uncertainty at project inception (the decision to commit funds for feasibility) and at the multiple decision points through the life-cycle. We also need to bear in mind that some projects are intrinsically more uncertain than others - decision-making regarding a new bridge is likely more uncertain than a new school. This can be defined as the level of project mission uncertainty. As the sequence of decisions is made and more information is acquired about the project through the life-cycle the level of decision-making uncertainty falls - this can be defined as the level of dynamic uncertainty on the project (Winch 2010). For instance, agreements with stakeholders will reduce the threat that they will disrupt project progress and ground investigations reduce uncertainty to risk for structural engineers. Typically this fall in the level of uncertainty is stepped through decision gates of greater or lesser informality working at greater levels of detail and lower levels of uncertainty. Thus choices between technology options will be made under higher levels uncertainty than decisions on the preparation of production drawings for the option selected. Certainty on the project is reached when the facility is finally completed and outturn costs and performance are known; however information on the revenues side of the investment case generated by the use of the facility typically remains incomplete even at this point. For instance, while certainty was achieved for investment expenditure on the Channel Fixed Link project in 1994, the revenues to provide a return on the investment remained uncertain and still do not meet expectations 20 years later (Winch 2013). 
Implications of the Information Processing Perspective for Research

We now turn to indicating some of the fresh and interesting lines of enquiry stimulated by this perspective on projects as information processing systems. One is around routines for "risk management"; a second is on the generation of hypotheses for task organisation and transaction governance. The fundamental premises of project risk management lie in the same neo-classical economics that the Carnegie School rejected - in particular the concepts of expected utility and subjective probability as captured in the probability/impact matrix (Winch and Maytorena 2011). Moving towards a more behavioural approach in the context of the project life-cycle suggests research attention to three important points. The first is that the term "risk" is unhelpful in this context. The managerial concern is to mitigate the threats to, and to enhance the opportunities for, the delivery of the facility in line with the business case that motivated the investment. Inevitably, the principal decisions regarding mitigation of perceived threats and enhancement of perceived opportunities are taken under high levels of uncertainty relatively early in the project life-cycle. The second point follows from this observation - we need much more research on the actual practice of managing threats and opportunities on projects. The experimental research of the heuristics and biases research programme (e.g. Kahneman et al 1982) has yielded many important insights, but that work is objectivist in that it typically uses known probabilities in experimental design. We need to know much more about how perceptions of threats and opportunities are generated under uncertainty and the role of the "illusion of control" (Langer 1975) and "optimism bias" (Weinstein 1980) in those perceptions. The work of Shapira (1995) is a start here from an organisation theory perspective, while Baddeley (2013) explores the implications from a behavioural economics perspective.

A third point is that the foundation of conventional project risk management techniques in subjective probabilities is often obscured in the presentation of the results of the risk 
analysis. The future is, by definition, unknown. All we have is our perceptions about the future state based on past experience. This past experience may or may not be relevant to the future state, and we have no way of being sure that past experience will hold good. Of course, past experience is more likely to be a good guide to the future in matters of engineering science (this column will stay up for $\mathrm{x}$ years so long as design assumptions hold) than matters of economic science (the expected use of this toll bridge in $x$ years time is $y$ journeys per day). Threats and opportunities are perceived possible events at some point in the future (possibly many years hence), yet the calculation is often presented without a time dimension and presented as a "fact" so that a P90 calculation is seen as an objective truth rather than a subjective assessment. Knight and Keynes both understood this point, and as Keynes famously argued, "we have to admit that our basis of knowledge for estimating the yield ten years hence of a railway, a copper mine, a textile factory, the goodwill of a patent medicine, an Atlantic liner, a building in the City of London amounts to little and sometimes nothing" (1961: 149). His solution to why investors still promoted projects in the face of such uncertainty was the "animal spirits" of the entrepreneur, not the tools of investment appraisal.

The perspective on projects as a problem in information also suggests some interesting hypotheses regarding differences in work organisation and organisation design between the earlier and later phases of a project. A basic premise of the contingency literature is that differences in levels of uncertainty in task execution lead to important differences in work organisation. The observable differences in the work organisation of architectural design and bricklaying are stark; similarly architectural practices are organised very differently from brickwork subcontractors. In the loosely coupled world of traditional project organisation, this observation had few managerial implications, but as we move to more integrated project organisations significant challenges do begin to emerge. For 
instance, is a single prime contractor capable of effectively managing both conceptual design and on-site execution, or should the client organization take more responsibility for overall project management, procuring the relevant specialists as they are needed through the life-cycle thereby eliminating the first tier of the supply chain?

Another important stream of work flowing from the Carnegie School is transaction cost economics. This has already had an important impact on our understanding of the procurement process, or stated more generally, the governance of inter-firm relations within the project coalition (Chang 2013; Chang and Ive 2007a; Chang and Ive 2007b; Ive and Chang 2007; Ive and Rintala 2006; Sha 2011). From a transaction cost economics perspective, the governance of the project coalition is also a problem in information in interaction with asset specificities (Winch 2001). Asset specificities at the pre-contract stage are associated with market monopoly and are rare in construction. The issues in construction mainly occur after the "fundamental transformation" (Williamson 1985) when the contract has been formed and generates temporal specificities through the project lifecycle due to switching costs. At least two sets of research questions flow from this theoretical insight.

The first is the post-contractual reversal of bargaining power (Chang and Ive 2007b). Suppliers of construction services typically deploy general-purpose skills and equipment on projects; as a result, they are easily switched to other uses should there be a dispute with the owner and investor in the project. Owners and investors, on the other hand, have typically sunk considerable capital into the project and only have a hope of gaining a return on that investment if the facility is completed. This generates some important dynamics on the project (Winch 2010). One is that there is a strong tendency towards the "escalation of commitment" (Staw 1981; 1997) to projects by owners and operators as budgets rise and 
schedules lengthen when switching investment out of the project would be the wiser course. Where the promoter of the project is not also the investor - as frequently happens in infrastructure investments (whether publicly or privately funded) - promoters can play on the effective "lock-in" of the investor into the project to strategically misrepresent the original business case (Flyvbjerg et al 2003) and thereby gain investor support for a project with poor financial prospects. The prime contractor can then be cast as the scapegoat for the inevitable project escalation. For example, these dynamics mutually reinforced each other on the Channel Fixed Link project (Winch 2013). We suggest that much more attention needs to be given to the power imbalances between investor, promoter, owner and supplier within the project coalition.

Posing projects as a problem in information also allows the generation of research questions regarding variety in the myriad different contracts in the overall "nexus of treaties" (Aoki et al 1990) that characterises the governance of the project coalition. Procurement research has overwhelmingly focused on only one particular contractual relationship - that between the owner and its tier one supplier of site execution services (aka the contractor). This is, of course, usually by far the largest contract in the nexus by value, but is it the most important? The work of Pryke (2012) using social network analysis suggests that we need to conceptualise project coalitions as more as networks rather than the hierarchies implied by the principal/agent relationship between the owner and its tier one supplier.

We have argued that a focus on the project as a problem in information can generate different insights into our understanding of construction projects and their management, but it begs the question of a "problem for whom"? We propose that it is principally a problem for the owner of the project who is also normally the operator of the facility the 
project is creating. The owner may also be the investor; where it is not, a further dimension is added to the diverse incentives within the project owner around the potential for strategic misrepresentation within the client. Recent research has developed the notion of the "intelligent client" (Aritua et al 2009; 2011; Boyd and Chinyo 2006). This development is welcome, but, we suggest, does not go far enough. The concept of "client" suggests one party in a commercial transaction, but clients, we argue, need to do more to solve their problem of information than improve their commercial skills. The owner of the project owns, first and foremost, the business case for investment in the facility delivered by the project which defines the project mission. From a behavioural perspective, unless this business case for investment is clearly articulated and the defended through the project lifecycle then the final facility will likely be a disappointment; only the owner can defend the business case for investment because it is the only member of the project coalition that is motivated solely by that case. Other parties are principally motivated by their particular contribution to the project and the returns to their involvement in the project. We therefore prefer the title of "owner" to that of "client" which retains too commercial a connotation (Winch 2014).

These considerations leave open the very important question of how much the owner should be doing on the management of its projects. Research in oil and gas sector (Merrow 2011) by Independent Project Analysis (IPA) suggests that it is a lot more than is normally the case in construction. IPA finds that one of the main causes of project failure is an understaffed owner project team, and that North Sea alliance-type contracting produces poor project performance because it encourages the owner to leave too much of the management of the project to the prime contractor. For instance, IPA show that the owner's development of the project execution plan is vital for high project performance; only if this is done does the owner have a sound basis to challenge the project execution 
plan proposed by the prime contractor and thereby ensure that it is aligned with owner requirements rather than the contractor requirements. Highest performance in this respect is achieved when the owner and prime contractor merge their project execution plans through negotiation. There is a significant new research agenda here in terms of the capabilities required by owners with respect to their projects and how oversight of the project process is best achieved.

Looking at Microfoundations

Behavioural plausibility is central to the Carnegie School and its challenge to the neoclassical economic paradigm (Gavetti et al 2012). Behavioural plausibility implies a well articulated "model of man" (Simon 1957) as a decision-maker to underlie the behavioural analysis. Recent debates have reinforced this point (e.g. Devinney 2013), and suggest that attention to the microfoundations of the information processing perspective articulated here is warranted. The rational actor model which underlies neo-classical economics, the decision sciences, and much strategic management theory is of a fully rational maximiser who carefully evaluates the available options on the basis of complete information in the light of utility preferences. The Carnegie School - led by Simon - replaced this model with that of a boundedly rational satisficer who selects the first option that meets minimum satisfactory requirements in the light of incentives.

Both of these models place rationality at their hearts (Van de Ven and Lifschitz 2013); the Carnegie School is merely more realistic in the behavioural plausibility of the model and rejects Friedman's methodological injunction. However, Van de Ven and Lifschitz (2013) argue that this model remains inadequate due to its emphasis on rationality. Drawing on jurisprudence and "old institutionalism" rather than economics, they suggest that a model of "reasonableness" rather than rationality where prudent decision-makers make sense of 
the situation to select appropriate choices in the light of social norms of reasonable behaviour. They argue that the notion of reasonableness is tested every day and well established by precedent in, for instance, cases under the law of tort such as professional negligence. Thus, Blyth v. Company Proprietors of the Birmingham Water Works, (156 ER 1047 Exchequer 1856) held that:

Negligence is the omission to do something which a reasonable man, guided upon those considerations which ordinarily regulate the conduct of human affairs, would do, or doing something which a prudent and reasonable man would not do.

Table 1 (developed from Van de Ven and Lifschitz table 2013) compares and contrasts the boundedly rational satisficer model with one we have called the prudentially reasonable sensemaker model.

Van de Ven and Lifschitz (2013) go on to argue that the reasonableness microfoundation can "enrich" many mainstream theories of organisation and management, including the two espoused here - the behavioural theory of the firm and transaction cost economics. For behavioural theory, it is not clear why people follow the organisational routines even when it is not obviously in their self-interest to do so. From a prudentially reasonable sensemaker perspective, people do this because of the norms into which they are socialised in the organisation or profession. For instance, following safety procedures is not obviously self-interested, particularly when compounded by optimism bias ("it won't happen to me"), but can be well understood as reasonable behaviour in a social context of an abhorrence of unnecessary death and injury. The socially embedded nature of reasonable behaviour suggests that greater attention is needed to the industry culture, or, more specifically, the ways in which the "industry recipe" of construction (Winch 2010 table 2.1) was developed and has evolved. Although there has been much comment on the culture of the construction sector, it has received remarkably little research attention in its own right. 
Table 1 Here

Transaction cost economics has been strongly criticised for its microfoundational assumptions of opportunism (Ghoshal and Moran 1996), yet as discussed above, many have found it has offered insights not available from other perspectives, and the prudentially reasonable sensemaker model suggests one way forward. Indeed, such a way forward would strengthen the analysis of Williamson's (1975) concept of "atmosphere" in transaction governance and the role of the contextual norms restraining opportunism. This would be based on emphasising the joint nature of transactions and the need therefore to be evaluated from the joint values of the parties involved and the associated perceptions of prudent, reasonable behaviour. Such an approach would bring trust to the heart of transaction governance, rather than being conceptualised merely as a mitigator of opportunistic behaviour. It would also likely generate new insights into the relational aspects of transaction governance and conflate the distinction articulated by Popper and Zenger (2002) between the relational and contractual aspects of governance. There is now a considerable body of research on relational aspects of construction projects (e.g. Pryke and Smyth 2006), particularly as information processed in these relationships has grown with the move from procuring assets to procuring performance (Caldwell and Howard 2010), but this work has not been particularly well grounded in organisation theory. The perspective on projects as information processing systems advocated here could do much to make that connection, and thereby enrich notions of trust (Smyth 2006) in construction management research.

Broader Perspectives from Organization Theory 
The Carnegie School perspective is, of course, not the only perspective from organisation theory which can be applied to the construction project management domain to yield new insights. Most notably, the neo-institutionalist perspective places less emphasis than Carnegie on the cognitive constraints faced by decision-makers and more on how actors construct the reality around them through interaction, thereby performing scripts and routines to generate organisation. The neo-institutionalist perspective is a broad one (Greenwood et al 2008; Powell and DiMaggio 1991), and includes contributions drawing on approaches such as diverse as ethnography, social network analysis, and discourse analysis. Some work explores isomorphism in organisational fields, while other work explores how actors construct their organisational reality through discourse. Such perspectives have the potential to generate significant insights into the management of construction projects (Chi and Javernick-Will 2011; Scott et al 2011). In particular, the perspective's emphasis on the embeddedness of behaviour in institutions could well support the development of organisation theory based on the prudentially reasonable sensemaker summarised in table 1. It should, however, be noted that the neo-institutionalist perspective evolved from a critique of the "old" institutionalism which underlies Van de Ven and Lifschitz' (2013) concept of reasonableness, and would tend to reject the concept of a "model of man" in favour of exploring how that model is constructed through everyday interaction (Powell and Colyvas 2008.

Another important stream of organisation theory is critical management studies, which is a similarly broad church (Alvesson et al 2009). While it has important similarities to neoinstitutionalism, particularly in terms of its emphasis upon how social realities are constructed and an emphasis on practice, it differs from the neo-institutionalist research through emphasising "discipline" and non-human "actants". Drawing more on French sociology as epitomised by thinkers such as Bourdieu, Foucault, and Latour, this perspective 
has become influential in project management research more generally (Hodgson and Cicmil 2006) and has yielded some important contributions to construction management research. These include contributions that draw on Foucault such Clegg et al (2002) and Schweber (2013), and contributions that draw on actor-network theory and practice-based perspectives (Bresnen et al 2005; Bresnen and Harty 2010; Chan and Räisänen 2009; Sage

et al 2011). Research on how identities are constructed at work (Brown and Phua 2011; Phua 2012) also has the potential for new insights in many areas, particularly ethics and trust, which would be relevant to the prudentially reasonable sensemaker model. Although not necessarily under a critical management studies label, Weick offers rich insights into organisational sensemaking (Wichk 1995; Weick et al 2010) including insights into intrasubjective (individual) and inter-subjective (collective) behaviour, how sensemakers are shaped by self-identities, and how they are constrained by target audiences (e.g. sensegiving). This perspective has been influential in project management research (e.g. Thiry, 2002) and in the specific context of construction (e.g. Green, 2011). However, it should be noted that a critical management approach would reject the notion of a microfoundational "model of man" underpinning organisation theory and shift attention to how that perceived model was both constructed and imposed through "discipline".

\section{Concluding Thoughts}

This contribution to the Festschrift in honour of Graham Ive has attempted to think through the implications of conceptualising projects as a problem in information, and the organisational information processing systems that address that problem to bring the desires of the promoter of the project to successful manifestation in concrete, steel and glass. The seed of this perspective was planted in the rich tilth of the MSc in Construction Economics and Management at the Bartlett in the early 1990s and germinated in interaction with Graham Ive as we taught that programme together. Theoretically, it drew 
inspiration from the work of the Carnegie School, and so we have reviewed some of the applications of the work of the Carnegie School to research in construction project management. We have also gone beyond that review through attention to the microfoundations of organisation and suggested that a prudentially reasonable sensemaker model of man would both yield significant additional insights, and also address some of the understandable concerns of those who are reluctant to build on the insights available from transaction cost economics due to its reliance on a boundedly rational satisficer model as summarised in table 1.

Underpinning the argument is a concern that the field of construction project management shares with the field of project management more generally (Scott et al 2011) a reluctance to engage with mainstream organisation theory. Arguably, this is the intellectual manifestation of the predominant industry culture that construction is different, and cannot learn from sectors such as manufacturing. A whole series of initiatives in the UK (including Construction as a Manufacturing Process and the Egan Report) and elsewhere has stressed that this self-imposed isolation is unacceptable. Arguably it is also unacceptable intellectually. We have here proposed the Carnegie School tradition of organisation theory as one robust way to make that bridge. It is made in the aspiration that the traffic across the bridge should be two way. The challenges of managing projects are immense and many organisation theory perspectives have difficulty gaining traction in this context. Mainstream organisation theories tend to focus on the temporary organisation (Bakker 2010), but this is only one aspect of project organising (Winch 2014) and research and theorising on organisations in the construction sector could have an important contribution to make to mainstream organisation theory. 
References

Aoki, M. Gustafsson, B. and Williamson, O.E. (eds.) (1990) The Firm as a Nexus of Treaties. London, Sage.

Alvesson, M. Bridgman, T. and Willmott, H. (eds.) (2009) The Oxford Handbook of Critical Management Studies. Oxford, Oxford University Press.

Aritua, B. Male, S. and Bower, D. (2009) Defining the Intelligent Public Sector Construction Client. Proceedings of the Institution of Civil Engineers: Management Procurement and Law. 162, 75-82.

Aritua, B. Male, S. Bower, D. and Madter, N. (2011) Competencies for the Intelligent Public Sector Construction Client. Proceedings of the Institution of Civil Engineers: Management Procurement and Law. 164, 193-201.

Baddeley, M. (2013) Behavioural Economics and Finance. London, Routledge.

Bakker, R.M. (2010) Taking Stock of Temporary Organizational Forms: A Systematic Review and Research Agenda. International Journal of Management Reviews. 12, 466-486.

Boyd, D. and Chinyo, E. (2006) Understanding the Construction Client. Oxford, Blackwell.

Bresnen, M. Goussevskaia, M. and Swan J. (2005) Editorial: Managing Projects as Complex Social Settings. Building Research \& Information. 33. 487-493

Bresnen, M. and Harty, C. (2010) Editorial: Objects, Knowledge Sharing and Knowledge Transformation in Projects. Construction Management and Economics. 28, 549-555.

Brown, A.D. and Phua, F.T.T. (2011) Subjectively Construed Identities and Discourses: Towards a Research Agenda for Construction Management. Construction Management and Economics. 29, 83-95.

Caldwell, N. and Howard, M. (eds.) (2010) Procuring Complex Performance: Studies of Innovation in Product-Service Management. London: Routledge. 
Chan, P. W. and Räisänen C. (2009) Editorial: informality and emergence in construction. Construction Management and Economics. 27, 907-912

Chang, C-Y. (2013) Understanding the Hold-up Problem in the Management of Megaprojects: The Case of the Channel Tunnel Rail Link Project. International Journal of Project Management. 31, 628-637.

Chang, C-Y. and Ive, G. (2007a) The Hold-up Problem in the Management of Construction Projects: A Case Study of the Channel Tunnel International Journal of Project Management. 25, 394-404.

Chang, C-Y. and Ive, G. (2007b) Reversal of Bargaining Power in Construction Projects: Meaning, Existence and Implications. Construction Management and Economics. 25, 845-855.

Chi, C.S.F. and Javernick-Will, A.N. (2011) Institutional Effects on Project Management: High-speed Rail Project in China and Taiwan. Construction Management and Economics. 29, 595-611.

Clegg, S. R. Pitsis, T. S. Rura-Polley, T. and Marosszeky, M. (2002) Governmentality Matters: Designing an Alliance Culture of Inter-organizational Collaboration for Managing Projects. Organization Studies. 23, 317-337.

Cleland, D.I. and King, W.R. (1983) Systems Analysis and Project Management (3rd ed.). New York, McGraw-Hill.

Cohen, M.D. (2007) Administrative Behavior: Laying the Foundations for Cyert and March. Organization Science. 18 503-506.

Cyert, R.M. and March, J.G. (1992) A Behavioral Theory of the Firm (2nd ed.). Oxford, Blackwell. 
Devinney, T.M., (2013) Is Microfoundational Thinking Critical to Management Thought and Practice? Academy of Management Perspectives. 27 81-84.

Flyvbjerg, B. Bruzelius, N, and Rothengatter, W. (2003) Megaprojects and Risk: An Anatomy of Ambition. Cambridge, CUP.

Friedman, M. (1953) Essays in Positive Economics. Chicago, The University of Chicago Press.

Galbraith, J. R. (1970). Environmental and Technological Determinants of Organization Design. In: Lorsch, J.W. and Lawerence, P.R. (eds.) Studies in Organization Design. Homewood IL, Irwin-Dorsey pp 113-139.

Galbraith, J.R. (1977) Organization Design. Reading NJ, Addison-Wesley.

Gavetti, G. Greve, H.R. Levinthal, D.A. and Ocasio, W. (2012) The Behavioural Theory of the Firm: Assessment and Prospects. Academy of Managment Annals. 6, 1-40.

Gavetti, G. Levinthal, D. and Ocasio, W. (2007) Neo-Carnegie: the Carnegie School's Past, Present, and Reconstructing for the Future. Organization Science. 18, 523-536.

Ghoshal, S. and Moran, P. (1996) Bad for Practice: A Critique of Transaction Cost Theory. Academy of Management Review. 21, 13-47.

Green, S. D. (2011) Making Sense of Construction Improvement. Chichester, Wiley.

Greenwood, R. Oliver, C. Sahlin, K. and Suddaby, R. (2008) (eds.) The Sage Handbook of Organizational Institutionalism. London, Sage.

Gruneberg, S. and Ive, G. (2000) The Economics of the Modern Construction Firm. Basingstoke, Macmillan.

Hodgson, D. Cicmil, S. (2006) (eds.) Making Projects Critical. Basingstoke, Palgrave Macmillan. 
Ive. G. and Chang, C-Y. (2007) The Principle of the Inconsistent Trinity in the Selection of Procurement Systems. Construction Management and Economics. 25, 677-690.

Ive, G. and Gruneberg, S. (2000) The Economics of the Modern Construction Sector. Basingstoke, Macmillan.

Ive, G. and Rintala, K. (2006) The Economics of Relationships. In: Pryke and Smyth (eds.): 282-302.

Kahneman, D. Slovic, P. and Tversky, A. (eds.). (1982). Judgement under uncertainty; heuristics and biases. Cambridge University Press. Cambridge.

Kast, F.E. and Rosenzweig, J.E. (1974) Organization and Management: A Systems Approach (2nd ed.) New York, McGraw-Hill.

Katz, D. and Kahn, R.L. (1978) The Social Psychology of Organizations $\left(2^{\text {nd }}\right.$. ed). New York, John Wiley.

Keynes, J. M. (1937) The General Theory of Employment. The Quarterly Journal of Economics. 209-223.

Keynes, J. M. (1961) The General Theory of Employment, Interest and Money. Macmillan. London.

Knight, F.H. (2002) Risk, Uncertainty and Profit. Beard Books. Washington DC

Langer, E.J. (1975) The Illusion of Control. Journal of Personality and Social Psychology. 32 311-328.

Macneill, I. (2001) The Relational Theory of Contract. London, Sweet \& Maxwell.

March, J. and Simon, H.A. (1993) Organizations (2nd ed.). Oxford, Blackwell.

Masten, S.E. Meehan, J.W. and Synder, E.A. (1991) The Costs of Organization. Journal of Law, Economics and Organization. 7, 1-25. 
Merrow, E. (2011) Industrial Megaprojects: Concepts, Strategies, and Practices for Success. Hoboken NJ: Wiley.

Perrow, C. (1967) A Framework for the Comparative Analysis of Organizations. American Sociological Review. 32, 194-208.

Phua, F.T.T. (2013) Construction Management Research at the Individual Level of Analysis: Current Status, Gaps and Future Directions. Construction Management and Economics. 31, 167-179.

Poppo, L. and Zenger, T. (2002) Do Formal Contracts and Relational Governance Function as Substitutes or Complements? Strategic Management Journal. 23, 707-725.

Porter, M.E. (1985) Competitive Advantage: Creating and Sustaining Superior Performance. New York, Free Press.

Powell, W.W. and Colyvas, J.A. (2008) Microfoundations of Institutional Theory. In Greenwood et al (eds.): 276-298.

Pryke, S. (2012) Social Network Analysis in Construction. Oxford, Wiley-Blackwell.

Pryke, S. and Smyth, H. (eds.) (2006) The Management of Complex Projects: A Relationship Approach. Oxford, Blackwell.

Sage, D. Dainty, A. and Brookes, N. (2011) How Actor-network Theories Can Help in Understanding Project Complexities. International Journal of Managing Projects in Business. 4, 274-293.

Scott, W.R. Levitt, R.E. and Orr, R.J. (2011) Global Projects: Institutional and Political Challenges. Cambridge, Cambridge University Press.

Schweber, L. (2013) The Effect of BREEAM on Clients and Construction Professionals. Building Research \& Information. 41, 129-145. 
Sha, K. (2011) Vertical Governance of Construction Projects: an Information Cost Perspective. Construction Management and Economics. 29, 1137-1147.

Shapira, Z. (1995). Risk taking: A managerial perspective. Russell Sage, New York

Shapira, Z. and Berndt, D. (1997) Managing grand scale construction projects: A risk taking perspective. Research in Organizational Behavior. 19, 303-360.

Simon, H. A. (1957) Models of Man; Social and Rational. Oxford, Wiley.

Simon, H. (1947) Administrative Behavior. Macmillan, New York.

Smyth, H. (2006) Measuring, Developing and Managing Trust in Relationships. In: Pryke and Smyth (eds.): 97-120.

Staw, B.M. 1981. The Escalation of Commitment to a Course of Action. Academy of Management Review. 6, 577-587.

Staw, B.M. 1997. The Escalation of Commitment: an Update and Appraisal. In: Z. Shapira (ed.) Organizational Decision Making Cambridge, CUP.

Stinchcombe, A.L. (1990) Information and Organizations. Berkeley, University of California Press.

Thiry, M. (2002) Combining Value and Project Management into an Effective Programme Management Model. International Journal of Project Management, 20, 221-227.

Van de Ven, A.H. and Lifschitz, A. (2013) Rational and Reasonable Microfoundations of Markets and Institutions. Academy of Management Perspectives. 27 156-172.

Weick, K.E. (1995) Sensemaking in Organizations. Thousand Oaks, Sage.

Weick, K. E. Sutcliffe, K. M. and Obstfield, D. (2010). Organizing and the Process of Sensemaking. In P. C. Nutt and Wilson, D. (eds.), Handbook of decision making. Chichester, Wiley, 83-104. 
Weinstein, N.D. (1980) Unrealistic Optimism about Future Life Events. Journal of Personality and Social Psychology. 39, 806-820.

Williamson, O.E. (1975) Markets and Hierarchies: Analysis and Anti-Trust Implications. New York, Free Press.

Williamson, O.E. (1985) The Economic Institutions of Capitalism. New York, The Free Press.

Winch G. M. (1989) The Construction Firm and the Construction Project: A Transaction Cost Approach Construction Management and Economics 7, 331-345.

Winch, G. M. (2001) Governing the Project Process: A Conceptual Framework Construction Management and Economics 19, 799-808.

Winch, G.M. (1994) Managing Production: Engineering Change and Stability. Oxford, Oxford University Press.

Winch, G. M. (2002) Managing Construction Projects: An Information Processing Approach. Oxford, Blackwell.

Winch, G. M. (2010) Managing Construction Projects: An Information Processing Approach ( $2^{\text {nd }}$ ed.). Oxford, Wiley-Blackwell.

Winch, G.M. (2013) Escalation in Major Projects: Lessons from the Channel Fixed Link. International Journal of Project Management. 31, 724-734. DOI: 10.1016/j.ijproman.2013.01.012.

Winch, G.M. (2014) Three Domains of Project Organising. International Journal of Project Management. 32, 721-731. DOI: 10.1016/j.ijproman.2013.10.012

Winch, G.M. (in press) Strategic Business and Network Positioning for Internationalisation. Service Industries Journal 
Winch, G. M. and Maytorena E.M. (2011) Managing Risk and Uncertainty: A Cognitive Approach In: P. Morris, J. Pinto, and J. Söderlund (eds.) Oxford Handbook of Project Management Oxford, OUP, 345-364.

Winch, G. M. and Schneider, E. (1993) Managing the Knowledge-Based Organisation; the Case of Architectural Practice Journal of Management Studies 30, 923-937. 


\begin{tabular}{|l|l|c|}
\hline & $\begin{array}{c}\text { Boundedly Rational } \\
\text { Satisficer }\end{array}$ & $\begin{array}{c}\text { Prudentially Reasonable } \\
\text { Sensemaker }\end{array}$ \\
\hline Definition & $\begin{array}{c}\text { "individually defined pursuit } \\
\text { of self and other } \\
\text { interests" }\end{array}$ & $\begin{array}{c}\text { collectively defined } \\
\text { appropriate behaviour } \\
\text { for role and } \\
\text { circumstance" }\end{array}$ \\
\hline Interactions & Opportunistic & Trustworthy \\
\hline Objectives & $\begin{array}{c}\text { Best available benefit in light } \\
\text { constraints cognitive }\end{array}$ & $\begin{array}{c}\text { "meet collective standard of } \\
\text { prudent, reasonable } \\
\text { person" }\end{array}$ \\
\hline Decision process & $\begin{array}{c}\text { What } \text { are the options that } \\
\text { meet my criteria? }\end{array}$ & $\begin{array}{c}\text { What sort of situation is } \\
\text { this? }\end{array}$ \\
\hline Decision criteria & $\begin{array}{c}\text { Which option best meets my } \\
\text { criteria? }\end{array}$ & $\begin{array}{c}\text { What is most appropriate for } \\
\text { me to do in this } \\
\text { situation? }\end{array}$ \\
\hline
\end{tabular}

Table 1 Microfoundations Compared: The Satisficing and Sensemaking Models of Man. (quotations from Van de Ven and Lifschitz 2013) 